\title{
PENERAPAN STRATEGI PEMBELAJARAN AKTIF TIPE CARD SORT UNTUK MENINGKATKAN HASIL BELAJAR KIMIA SISWA KELAS X
}

\author{
Resti Tri Astuti \\ Universitas Islam Negeri Raden Fatah Palembang \\ E-mail: restitriastuti@radenfatah.ac.id
}

\begin{abstract}
Abstrak: Penelitian ini bertujuan untuk mengetahui peningkatan hasil belajar siswa pada mata pelajaran kimia dengan menerapkan strategi pembelajaran aktif tipe card sort di kelas X.F SMA Negeri 1 Indralaya. Materi Yang digunakan dalam Penelitian ini yaitu materi hidrokarbon. Metode yang digunakan dalam penelitian ini adalah Penelitian Tindakan Kelas, dilakukan dalam tiga siklus. Teknik pengumpulan data menggunakan lembar observasi dan tes akhir siklus. Hasil penelitian menunjukkan rata-rata nilai hasil belajar siswa sebelum dilakukan tindakan $\left(\mathrm{T}_{0}\right)$ yaitu 62,3 dengan ketuntasan klasikal 33,33\%, siklus I $\left(\mathrm{T}_{1}\right)$ yaitu 64,46 dengan ketuntasan klasikal $57,14 \%$, siklus II $\left(\mathrm{T}_{2}\right)$ yaitu 73,83 dengan ketuntasan klasikal 73,33\% dan pada siklus III $\left(\mathrm{T}_{3}\right)$ yaitu $79,82 \%$ dengan ketuntasan klasikal $85,71 \%$. Hasil penelitian menunjukkan bahwa penerapan strategi pembelajaran aktif tipe card sort dapat meningkatkan hasil belajar kimia siswa. Peneliti memberikan saran kepada guru, sekolah, dan peneliti lain dapat menerapkan strategi pembelajaran aktif tipe card sort dikelas sebagai salah satu alternatif untuk meningkatkan hasil belajar siswa.
\end{abstract}

Kata kunci: hasil belajar, card sort, penelitian tindakan kelas

\section{PENDAHULUAN}

Pada penyelenggaraan pendidikan, prosesnya harus mengikuti kaidah agar sesuai dengan tujuan yang diinginkan, sehingga dapat mencetak hasil yang diinginkan. Hal ini diatur dalam PP No.19 Tahun 2005 Bab IV pasal 19 Ayat 1 yang menyatakan bahwa proses pembelajaran pada satuan pendidikan diselenggarakan secara interaktif, inspiratif, menyenangkan, menantang, memotivasi peserta didik untuk berpartisipasi aktif, serta memberikan ruang yang cukup bagi prakarsa, kreativitas, dan kemandirian sesuai dengan bakat, minat, dan perkembangan fisik serta psikologis peserta didik. Hal ini merupakan dasar bahwa guru perlu menyelenggarakan pembelajaran yang aktif, kreatif, efektif, dan menyenangkan.

Proses pembelajaran dikelas adalah salah satu tahap yang sangat menentukan keberhasilan siswa dalam belajar. Didalam proses belajar mengajar ini, guru harus memiliki strategi agar siswa dapat belajar secara efektif dan efisien. Penggunaan strategi belajar yang tepat dengan materi yang akan disampaikan merupakan salah satu usaha untuk meningkatkan hasil belajar siswa. Guru harus menguasai berbagai bentuk metode mengajar dan menggunakan metode mengajar yang sesuai untuk setiap materi yang akan diajarkannya. Keberhasilan proses belajar mengajar sangat ditentukan oleh kemampuan guru dalam mengelola proses belajar mengajar (Suryosubroto, 2007:17).

Berdasarkan data tahun 2011 yang diperoleh guru bidang studi kimia di SMA Negeri 1 Indralaya dikelas X.F, diketahui bahwa hasil belajar masih sangat rendah. Data persentase ketuntasan yang mendapatkan nilai di atas 70 hanya $33,33 \%$, sedangkan siswa yang mendapatkan nilai kurang dari 70 sebesar 66,67\%. kelas X.F, kondisi yang dijumpai yaitu guru jarang melakukan diskusi kelas, 
menyebabkan siswa belum berani untuk mengemukakan pendapat. Guru masih menerapkan metode ceramah dan latihan soal saat proses pembelajaran berlangsung, hal ini menjadikan siswa kurang tertarik dengan pembelajaran kimia. Penyampaian materi dengan metode ceramah yang terus menerus diterapkan dikelas menjadi kurang menarik dan pembelajaran terasa membosankan. Penggunaan metode ceramah ini menyebabkan siswa menjadi pasif dan kurang memperhatikan guru saat menjelaskan, ini terlihat hanya sebagian siswa saja yang memperhatikan penjelasan guru, selebihnya siswa sibuk dengan pekerjaannya seperti mengobrol dengan temannya, pandangan mata siswa sering keluar kelas, dan ada juga siswa yang mengerjakan tugas mata pelajaran lain.

Ketika guru memberikan latihan soal, siswa tidak ada yang berani untuk menjawab pertanyaan tersebut, jadi guru terpaksa menyebutkan nama siswa terlebih dahulu agar pertanyaan dapat dijawab oleh siswa, terkadang ada siswa yang meminjam buku temannya yang sudah menuliskan jawaban, sehingga siswa tersebut hanya menyalin jawaban itu tanpa mengerti apa yang mereka tulis dipapan tulis. Hal ini menunjukkan bahwa tingkat pemahaman siswa terhadap materi pelajaran masih rendah sehingga berdampak pada rendahnya hasil belajar siswa. Penggunaan metode ceramah bukan berarti tidak diperlukan saat pembelajaran tetapi perlu dikombinasikan dengan yang lain agar siswa menjadi lebih paham dalam menerima materi pelajaran.

Keadaan tersebut jika terus menerus masih belum diperbaiki dalam proses pembelajaran, maka siswa hanya terbiasa dengan proses belajar yang masih berpusat pada guru. Metode ceramah ini menyebabkan siswa hanya menerima informasi yang diberikan oleh guru tanpa mereka sendiri yang belajar untuk memahami materi. Metode ceramah juga akan menyebabkan siswa menjadi malas belajar dan siswa hanya mencatat penjelasan guru tanpa mengerti yang dicatat. Hal ini akan berdampak kepada hasil belajar yang masih rendah. Hasil belajar merupakan faktor yang sangat penting, karena hasil belajar yang dicapai siswa merupakan alat untuk mengukur sejauh mana penguasaan materi yang diajarkan guru.

Dalam dunia pendidikan, perlunya perbaikan proses pembelajaran, sehingga guru tidak lagi menjadi posisi sentral dalam proses pembelajaran, melainkan siswa itu sendiri. Membiasakan siswa menjadi posisi sentral akan berdampak baik pada hasil belajarnya. Siswa yang akan terlibat langsung dan berperan aktif dalam memahami materi. Semakin besar keterlibatan siswa dalam kegiatan pembelajaran, maka semakin besar baginya untuk mengalami proses belajar.

Cara yang dapat dilakukan oleh guru untuk memfasilitasi siswa antara lain dengan menciptakan lingkungan belajar yang kondusif dan memberikan bimbingan pada saat kegiatan belajar. Salah satunya dengan mencoba strategi pembelajaran aktif tipe card sort yang akan membuat proses belajar lebih menarik dan tidak membosankan. Strategi pembelajaran aktif dimaksudkan untuk mengoptimalkan penggunaan semua potensi siswa, sehingga siswa dapat mencapai hasil belajar yang memuaskan sesuai dengan karakteristik yang mereka miliki. Selain itu, strategi pembelajaran aktif juga dimaksudkan untuk menjaga perhatian siswa agar tetap tertuju pada proses pembelajaran. 
Dalam proses pembelajaran aktif akan terjadi interaksi siswa dengan siswa, siswa dengan guru atau siswa dengan sumber belajar lainnya. Sehingga siswa tidak terbebani secara individu dalam memecahkan masalah yang dihadapi dalam belajar, tetapi siswa akan saling bertanya dan berdiskusi tentang materi yang dipelajari. Card sort merupakan kegiatan yang bisa digunakan untuk mengajarkan konsep, penggolongan sifat, fakta tentang suatu objek, atau informasi dengan menggunakan kartu (Silberman, 2011: 169). Kartu sebagai media untuk menyampaikan informasi sehingga dapat merangsang perhatian, minat, dan pikiran dalam kegiatan belajar untuk mencapai tujuan belajar. Penerapan media harus dapat melatih cara-cara memperoleh informasi baru, menyeleksinya, dan kemudian mengolahnya sehingga terdapat jawaban dari suatu permasalahan. Dengan strategi pembelajaran aktif ini diharapkan akan tumbuh dan berkembang segala potensi yang siswa miliki sehingga pada akhirnya dapat mengoptimalkan hasil belajar siswa. (Uno dan Nurdin, 2012:10).

Penelitian pembelajaran aktif tipe card sort pernah dilakukan oleh Qomariah (2011) menunjukkan bahwa meningkatnya pemahaman membaca siswa meliputi ide pokok, informasi rinci dan makna kata. Rata-rata nilai meningkat dari siklus pertama ke siklus berikutnya. Selain itu, suasana kelas menjadi aktif dan hidup. Card sort dapat membuat kelas menjadi kondusif dan siswa juga dapat saling bekerjasama dengan baik. Penelitian juga pernah dilakukan oleh Pradina (2010) menunjukkan adanya peningkatan pemahaman konsep pada materi sistem reproduksi dengan ketuntasan belajar sebesar $91,2 \%$.

\section{METODE PENELITIAN}

Metode penelitian yang dilakukan adalah penelitian tindakan kelas (PTK). Penelitian ini dilakukan sebanyak tiga siklus. Setiap siklus terdiri atas empat tahap kegiatan yaitu: perencanaan, pelaksanaan tindakan, observasi dan refleksi. Penelitian dilakukan di semester genap tahun ajaran 2011/2012 di kelas X.F SMA Negeri 1 Indralaya. Subjek dalam penelitian ini adalah seluruh siswa kelas X.F SMA Negeri 1 Indralaya yang berjumlah 30 orang yang terdiri dari 9 orang lakilaki dan 21 orang perempuan.

Teknik pengumpulan data yang digunakan dalam penelitian ini, yaitu dengan tes dan observasi. Tes digunakan untuk mengumpulkan data hasil belajar siswa yang dilaksanakan disetiap akhir siklus. Data pelaksanaan kegiatan belajar siswa selama proses pembelajaran diperoleh dari hasil observasi dengan menggunakan lembar observasi. Observasi digunakan untuk mengetahui bagaimana tingkah laku, sikap serta partisipasi siswa dalam proses pembelajaran.

Analisis data digunakan yaitu sebagai berikut:

a. Kriteria Ketuntasan Minimal (KKM)

KKM mata pelajaran kimia di SMA Negeri 1 Indralaya sebesar 70. Ketuntasan belajar siswa dapat dilihat dari sisi individual dan klasikal. Ketuntasan belajar individual tercapai bila memperoleh $\geq 70$ dan ketuntasan klasikal tercapai jika kelas tersebut $85 \%$ siswa yang memperoleh skor $\geq 70$. Peningkatan hasil belajar siswa dapat dilihat dari nilai rata-rata siswa setiap siklusnya yaitu mulai dari $\mathrm{T}_{0}, \mathrm{~T}_{1}, \mathrm{~T}_{2}$, dan $\mathrm{T}_{3}$. Untuk mencari nilai rata-rata digunakan rumus: 


$$
\mathrm{X}=\frac{\sum x}{N}(\text { Sudjana, 2005:109) }
$$

Keterangan

$\mathrm{X}$ : Nilai rata-rata seluruh siswa

$\sum \mathrm{x}$ : Jumlah nilai seluruh siswa

$\mathrm{N}$ : Jumlah Seluruh Siswa

Setelah didapat data hasil belajar, maka hasil perhitungan dapat dikonversikan berdasarkan kriteria ketuntasan hasil belajar, sebagai berikut :

Tabel 1. Kategori Ketuntasan Hasil Belajar Siswa

\begin{tabular}{cc}
\hline Nilai & Kategori Ketuntasan \\
\hline $70-100$ & Tuntas \\
$0-69$ & Belum Tuntas \\
\hline
\end{tabular}

b. Data Observasi

Untuk melihat persentase keaktifan pada masing-masing deskriptor digunakan rumus:

$$
\%=\frac{\text { skor aktivitas }}{\text { skor total aktivitas }} \times 100 \%
$$

Keterangan:

- Skor aktivitas: Jumlah siswa yang melakukan aktivitas pada masing-masing deskriptor

- Skor total aktivitas: Jumlah siswa yang melakukan semua deskriptor

Persentase (\%) aktivitas kelas dengan menggunakan rumus:

$$
\%=\frac{\text { rata-rata keaktifan siswa }}{\text { jumlah siswa di kelas }} \times 100 \%
$$

\section{HASIL DAN PEMBAHASAN}

Hasil tes siklus I diperoleh persentase ketuntasan sebesar 57,14\% dengan rata-rata hasil belajar sebesar 64,46. Persentase keaktifan setiap kelompoknya yaitu $46,88 \% ; 51,67 \%$; 50,83\%; 46,67\%; 47,93\%; 38,84\%. Rata-rata persentase keaktifan siklus pertama yaitu $47,05 \%$. Kelompok yang memiliki hasil belajar tertinggi yaitu kelompok II dengan nilai rata-rata hasil belajar 78 dan keaktifan sebesar 51,67\%. Kelompok II telah memiliki kesiapan belajar, siswa aktif dalam berdiskusi, siswa juga sering bertanya dengan guru jika tidak mengerti.

Kelompok yang memiliki hasil belajar terendah yaitu kelompok VI dengan nilai rata-rata hasil belajar 49 dan keaktifan sebesar 38,34\%. Hal ini disebabkan kelompok VI hanya didominasi oleh 2 orang perempuan yang aktif berdiskusi, sedangkan 3 orang laki-laki banyak mengobrol, tidak ikut berdiskusi, dudukduduk santai menunggu jawaban dari teman sekelompoknya, mengumpulkan tugas terlambat, dan ketika diminta mempresentasikan, tidak ada yang bersedia untuk kedepan kelas, dan sering membuat keributan. Berdasarkan hasil observasi tersebut, maka 2 anggota dari kelompok VI dipindahkan ke kelompok IV dan 
kelompok V agar diskusi berjalan lancar dan semua kelompok aktif dalam proses pembelajaran.

Berdasarkan hasil belajar siswa dapat diketahui bahwa persentase ketidaktuntasan masih tinggi. Hal ini disebabkan karena masih terdapat kelemahan-kelemahan. Siswa juga belum terbiasa dengan pembelajaran menggunakan kartu. Beberapa siswa ada yang antusias dalam kegiatan mengelompokkan kartu, namun ada juga siswa yang tampak kebigungan dengan proses pembelajaran menggunakan kartu. Kerjasama dalam diskusi belum berjalan dengan baik untuk setiap kelompoknya. Siswa juga belum memanfaatkan kartu yang sudah disediakan secara maksimal. Beberapa siswa hanya mengandalkan siswa yang lebih pandai didalam kelompoknya. Pada kegiatan mempresentasikan, siswa saling menunjuk teman sekelompoknya untuk mempresentasikan kedepan kelas. Siswa banyak yang tidak memperhatikan penjelasan guru dikarenakan beberapa siswa mengobrol, pandangan mata yang sering menatap keluar kelas, melakukan aktivitas lainnya yang tidak berhubungan dengan proses pembelajaran.

Kelemahan-kelemahan dari siklus I, maka perlu adanya perbaikan dalam proses pembelajaran selanjutnya. Guru meminta setiap siswa membaca kartu yang sudah disediakan dan meminta siswa untuk semuanya ikut berdiskusi dalam kelompoknya. Guru juga memberikan motivasi agar siswa berperan aktif dan tidak saling menunjuk dalam mempresentasikan hasil diskusinya. Guru berkeliling saat diskusi untuk agar tidak ada siswa yang hanya mengandalkan temannya. Guru menegur siswa yang tidak memperhatikan agar mengerti tentang materi yang dipelajari.

Hasil belajar siklus II diperoleh ketuntasan dengan persentase 73,33\% dengan rata-rata hasil belajar sebesar 73,83 . Persentase keaktifan setiap kelompok pada siklus II yaitu 55,50\%; 60,00\%; 68,33\%; 58,33\%; 63,33\%; 63,33\%. Ratarata persentase keaktifan siswa siklus II yaitu $61,39 \%$. Kelompok yang memiliki hasil belajar tertinggi yaitu kelompok III dengan nilai rata-rata hasil belajar 89 dan keaktifan sebesar 68,33\%. Hampir semua anggota kelompok III ikut berdiskusi, saling memberikan pendapat dalam menjawab LKS, jika selesai menjawab LKS siswa kembali memeriksa jawabannya, membaca isi kartu berulang-ulang agar poin-poin penting dalam kartu dapat diingat oleh siswa untuk menjawab tes akhir siklus kedua.

Kelompok yang memiliki hasil belajar terendah yaitu kelompok I dengan nilai rata-rata hasil belajar 61 dan keaktifan sebesar 50\%. Hal ini disebabkan anggota kelompoknya lebih banyak mengobrol hal-hal yang tidak berhubungan dengan materi pelajaran, sedangkan dalam menjawab LKS hanya beberapa siswa, beberapa siswa baru ikut berdiskusi jika guru mendekati kelompoknya, kurangnya kesiapan belajar siswa, dan malu bertanya jika ada materi yang belum dipahami.

Berdasarkan tes hasil belajar siklus II, ketuntasan belajar telah mengalami peningkatan namun belum mencapai ketuntasan secara klasikal $85 \%$ serta keaktifan siswa juga telah mengalami peningkatan dari siklus I. Hal ini dikarenakan, siswa sudah mulai terbiasa belajar menggunakan kartu yang menjadikan siswa aktif dalam proses pembelajaran. Melalui penggunakan media pembelajaran berupa kartu, siswa tidak menyadari jika mereka sedang menghapal 
dan memahami materi yang dipelajari. Pada siklus II, interaksi antar siswa dalam diskusi kelompok sudah cukup baik, interaksi siswa dengan guru sudah terjadi namun hanya beberapa kelompok saja, dan interaksi siswa dengan media berupa kartu juga sudah terlihat meskipun belum secara maksimal. Namun pada siklus II masih terdapat kelemahan-kelemahan seperti beberapa siswa masih saja tidak memperhatikan penjelasan guru, karena mengobrol dengan teman sebangku dan melakukan aktivitas lainnya yang tidak berhubungan dengan materi pelajaran, siswa sulit membuat struktur senyawa hal ini dikarenakan struktur senyawa pada kartu sudah sangat jelas. Siswa masih belum berani dalam mempresentasikan hasil diskusinya secara mandiri. Tahap mempresentasikan siswa tidak menuliskan hasil presentasinya sehingga menjadikan siswa sulit menanggapi hasil diskusi kelompok mengenai struktur dan penamaan alkana, alkena, dan alkuna.

Berdasarkan hasil belajar yang belum mencapai ketuntasan klasikal, maka perlunya perbaikan untuk siklus III, diantaranya untuk meminimalisir siswa yang tidak memperhatikan pada siklus III maka guru bertanya kepada siswa yang tidak memperhatikan dan meminta siswa kedepan kelas untuk membuat struktur berdasarkan materi yang sudah dipelajari sebelumnya yaitu mengenai tata nama senyawa hidrokarbon, kartu dibuat menggunakan kertas berwarna agar siswa tertarik untuk membacanya. Kartu berisi tahapan-tahapan membuat struktur agar siswa belajar membuat struktur secara mandiri. Guru meminta siswa untuk mengambil dua setiap siswanya. Memberikan dua kartu kepada siswa menjadikan semua siswa terlibat aktif tanpa mengandalkan siswa lain dalam mengerjakan LKS. Guru lebih memotivasi siswa untuk terlibat aktif dalam diskusi. Melalui diskusi kelompok dapat mendorong siswa menjadi berinteraksi dan membantu memahami pendapat yang berbeda. Guru meminta siswa juga menuliskan struktur dan nama senyawa dipapan tulis, hal ini memudahkan siswa dari kelompok lain untuk menanggapi baik struktur dan nama senyawa yang kurang tepat.

Hasil tes siklus III diperoleh persentase ketuntasan sebesar $85,71 \%$ dengan rata-rata hasil belajar sebesar 79,82. Persentase keaktifan setiap kelompoknya yaitu kelompok I dan kelompok II yaitu 71,67\%; kelompok III 74,17\%; kelompok IV 66,67\%; kelompok V 76,67\%; kelompok VI 67,71. Rata-rata persentase keaktifan siklus ketiga yaitu $71,35 \%$. Pada siklus III mengenai materi isomer, siswa menjadi lebih mudah untuk membuat struktur berdasarkan tahapan-tahapan yang ada pada kartu dan siswa lebih mudah menanggapi hasil diskusi kelompok yang presentasi dengan menuliskan struktur dan nama senyawa dipapan tulis. Banyaknya siswa yang antusias untuk mempresentasikan hasil diskusi kelompoknya. Proses pembelajaran yang menarik dapat meningkatkan aktivitas belajar siswa, sehingga hasil belajar siswa pada siklus III juga mengalami peningkatan.

Kelompok yang memiliki hasil belajar tertinggi masih dipegang kelompok III dengan nilai rata-rata hasil belajar 85 dan keaktifan sebesar 74,17\%. Siswa tidak mengalami kesulitan dalam membuat struktur senyawa pada materi siklus ketiga, karena siswa sudah cukup baik dalam membuat struktur senyawa berdasarkan tes hasil belajar siklus II mengenai tata nama senyawa hidrokarbon. Pada dasarnya untuk menentukan isomer siswa harus bisa dalam membuat struktur. Oleh karena itu, tahapan-tahapan pada kartu memudahkan siswa belajar 
untuk membuat struktur secara mandiri. Siswa juga saling berdiskusi mengenai struktur yang sudah dibuat masing-masing siswa secara mandiri.

Kelompok yang memiliki hasil belajar terendah yaitu kelompok IV dan kelompok VI dengan nilai rata-rata hasil belajar 76,25 dan keaktifan kelompok IV sebesar 66,67\%, dan kelompok VI sebesar 67,71\%. Siswa diminta untuk menuliskan struktur secara mandiri berdasarkan kartu yang dipegang masingmasing siswa, namun masih saja siswa meminta teman satu kelompoknya untuk mengerjakannya. Beberapa siswa tidak bisa menuliskan struktur meskipun sudah dibuat tahapan-tahapannya dan siswa tidak saling berdiskusi mengenai jawaban yang telah dibuat masing-masing siswa.

Rekapitulasi Distribusi Frekuensi hasil belajar yang diperoleh selama proses pembelajaran mulai dari sebelum diberi tindakan $\left(\mathrm{T}_{0}\right)$ sampai dengan siklus III $\left(\mathrm{T}_{3}\right)$, dapat dilihat pada Tabel 2 berikut ini:

Tabel 2. Rekapitulasi Distribusi Frekuensi Hasil Belajar Siswa

\begin{tabular}{c|c|c|c}
\hline Tes & $\begin{array}{c}\text { Nilai Rata-rata } \\
\text { Hasil Belajar }\end{array}$ & $\begin{array}{c}\text { Jumlah siswa } \\
\text { yang tuntas }\end{array}$ & $\begin{array}{c}\text { Ketuntasan } \\
\text { klasikal }(\%)\end{array}$ \\
\hline $\mathrm{T}_{0}$ & 62,3 & 10 & 33,33 \\
$\mathrm{~T}_{1}$ & 64,46 & 16 & 57,14 \\
$\mathrm{~T}_{2}$ & 73,83 & 22 & 73,33 \\
$\mathrm{~T}_{3}$ & 79,82 & 24 & 85,71 \\
\hline
\end{tabular}

Berdasarkan Tabel 2 diatas menunjukkan bahwa pencapaian ketuntasan belajar siswa sudah sesuai yang diharapkan yaitu 85\% siswa memperoleh nilai lebih besar atau sama dengan 70 pada siklus ketiga. Peningkatan hasil belajar siswa sebelum diberi tindakan (To) sampai dengan siklus ketiga digambarkan dalam bentuk diagram batang pada Gambar 1 berikut:

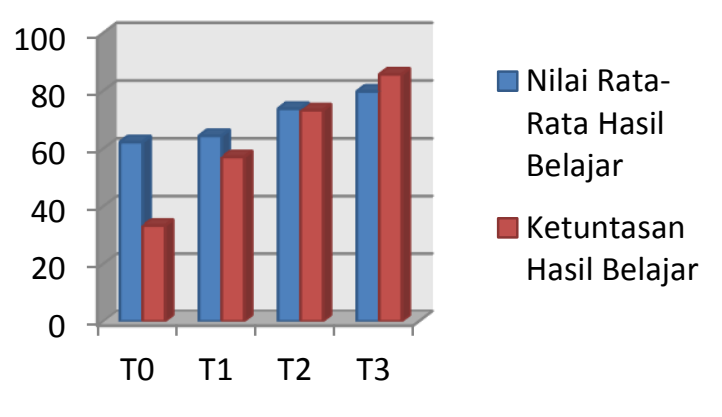

Gambar 1. Diagram Batang Ketuntasan Belajar Siswa dan Nilai Rata-Rata Hasil Belajar

Berdasarkan hasil tes belajar dari siklus I sampai dengan siklus III, didapatkan bahwa tidak semua siswa mengalami peningkatan hasil belajar setiap siklusnya. Berdasarkan wawancara langsung dengan beberapa siswa, siswa mengatakan bahwa pada proses pembelajaran siswa sering mengobrol dengan teman sekelompoknya, sehingga kurang memperhatikan saat guru menjelaskan dan tidak ikut berdiskusi. Aktivitas yang kurang baik ini, menyebabkan hasil belajar siswa menurun. 
Peningkatan hasil belajar siklus I sampai dengan siklus III, hal ini disebabkan karena siswa sejak awal kegiatan sudah dilibatkan secara aktif dalam pembelajaran. Hal ini sesuai dengan penelitian sebelumnya oleh Haryanto (2011) bahwa terdapat perbedaan yang signifikan antara kelas ekperimen dan kelas kontrol. Dalam pembelajaran aktif siswa menjadi lebih aktif dalam mempelajari materi pelajaran, proses diskusi menjadikan siswa aktif dalam mengemukakan pendapat dan saling membagi pengetahuan. Hal ini didukung oleh pernyataan Muhtadi (2009).

Strategi pembelajaran aktif tipe card sort dapat digunakan untuk mengajarkan konsep dan keterlibatan siswa dalam memegang kendali dalam proses pembelajaran, hal ini akan menciptakan suasana yang menyenangkan. Card sort membantu siswa memahami materi dan memudahkan siswa mengingat rumus-rumus kimia (Morris, 2011). Diskusi kelompok dalam strategi ini juga mendorong siswa untuk berbagi ide dalam kelompoknya sehingga terjadi interaksi antar siswa. Hal yang sama diungkapkan oleh Boyle dan Jackson (2005).

Dari penelitian yang dilakukan terdapat kelemahan dari strategi pembelajaran aktif tipe card sort yaitu diperlukan waktu yang lama karena pembuatan kartu yang banyak untuk setiap kelompoknya.

\section{KESIMPULAN DAN SARAN}

\section{Kesimpulan}

Berdasarkan hasil penelitian dan pembahasan yang telah diuraikan, dapat disimpulkan bahwa melalui strategi pembelajaran aktif tipe Card Sort hasil belajar kimia siswa kelas X.f SMA Negeri 1 Indralaya dapat meningkat. Hal ini dibuktikan dengan ketuntasan belajar siswa mencapai Kriteria Ketuntasan Minimal (KKM) di SMA Negeri 1 Indralaya yaitu yang memperoleh nilai $\geq 70$ pada siklus I sebesar $64,46 \%$ (16 orang), siklus II sebesar 73,33\% (22 orang) dan siklus III sebesar $85,71 \%$ (24 orang). Melalui strategi pembelajaran aktif tipe card sort ini pada umumnya semua siswa menunjukkan peningkatan keaktifan siswa dimana dengan menggunakan dua kartu untuk setiap siswa membantu kemandirian belajar siswa dan saling berbagi pengetahuan antar siswa dalam proses diskusi.

\section{Saran}

Berdasarkan penelitian yang telah dilakukan, disarankan kepada Bagi guru dalam Kegiatan Belajar Mengajar (KBM) di kelas dapat mengembangkan kreativitas agar kartu yang digunakan lebih menarik perhatian siswa dalam belajar agar hasil belajar yang diharapkan dapat tercapai. Bagi sekolah dalam rangka perbaikan pembelajaran dan upaya meningkatkan kualitas pembelajaran menggunakan media kartu. Bagi peneliti selanjutnya disarankan mengembangkan pembelajaran yang mengedepankan keaktifan siswa terutama membuat siswa lebih aktif dalam menyampaikan pendapat serta membagi informasi dengan teman menggunakan strategi pembelajaran aktif tipe card sort. 


\section{DAFTAR PUSTAKA}

Boyle,M., PJ. (2005). Using Card Sort. Briefing paper 11 Version 1 Issued July 2005. http://www.heacademy.ac.uk/.

Haryanto. 2011. Pengaruh Strategi Pembelajaran Aktif Card Sort dan Index Card Match Terhadap Prestasi Belajar Getaran dan Gelombang. JP2F. Volume 2 Nomor 2. Hal 165-174.

Morris, Todd. 2011. A Card Game To Help Students Learn Chemical Formulas. Journal of Chemical Education. Vol 88 Nomor (10). Hal.1397-1399.

Muhtadi, Ali. 2009. Implementasi Konsep Pembelajaran Active Learning Sebagai Upaya Meningkatkan Aktifitas Mahasiswa dalam Perkuliahan. Majalah Ilmiah Pembelajaran, Volume 5 Nomor (1). Hal 28-38. http://isjd.pdii.lipi.go.id/admin/jurnal/51092838_0216-7999.pdf.

Pradina, Resti Ari. 2010. Penguasaan Konsep Sistem Reproduksi Dengan Pembelajaran Aktif Menggunakan Kartu Sortir. Skripsi. Bandung: Universitas Pendidikan Indonesia.

Qomariah. 2011. Using Card Sort Technique to Improve the Students' Reading Comprehension (A Classroom Action Research at the eighth Grade Students of SMP Negeri 3 Purwodadi in the Academic Year of 2010/2011). Thesis. Surakarta. Graduate School, Sebelas Maret University.

Silberman, Mel. 2011. Active Learning 101 Cara Belajar Siswa Aktif. Bandung: Nusamedia.

Sudjana, N. 2005. Penilaian Hasil Proses Belajar Mengajar. Bandung: PT Remaja Rosdakarya.

Suryosubroto.2007. Proses Belajar Mengajar di Sekolah. Jakarta: Rineka Cipta.

Uno, Hamzah, Nurdin Mohamad. 2012. Belajar dengan Pendekatan PAILKEM. Jakarta: Bumi Aksara. 